Article

\title{
Carbon Budgets for Caribbean Mangrove Forests of Varying Structure and with Phosphorus Enrichment
}

\section{Catherine E. Lovelock $^{1, *}$, Lorae T. Simpson ${ }^{2,3}$, Lisa J. Duckett ${ }^{2}$ and Ilka C. Feller ${ }^{2}$}

1 School of Biological Science, The University of Queensland, St Lucia, Queensland 5072, Australia

2 Smithsonian Environmental Research Center, 647 Contees Wharf Rd, Edgewater, MD 21037, USA; E-Mails: simpsonl@si.edu (L.T.S.); duckettl@si.edu (L.J.D.); felleri@si.edu (I.C.F.)

3 Smithsonian Marine Station at Fort Pierce, 701 Seaway Dr, Fort Pierce, FL 34949, USA

* Author to whom correspondence should be addressed; E-Mail: c.lovelock@uq.edu.au; Tel.: +61-7-3365-2304; Fax: +61-7-3365-4075.

Academic Editor: Mark E. Harmon

Received: 13 August 2015 / Accepted: 28 September 2015 / Published: 7 October 2015

\begin{abstract}
There are few detailed carbon (C) budgets of mangrove forests, yet these are important for understanding $\mathrm{C}$ sequestration in mangrove forests, how they support the productivity of the coast and their vulnerability to environmental change. Here, we develop $\mathrm{C}$ budgets for mangroves on the islands of Twin Cays, Belize. We consider seaward fringing forests and interior scrub forests that have been fertilized with phosphorus $(\mathrm{P})$, which severely limits growth of trees in the scrub forests. We found that respiration of the aboveground biomass accounted for $60 \%-80 \%$ of the fixed $\mathrm{C}$ and that respiration of the canopy and aboveground roots were important components of respiration. Soil respiration accounted for only $7 \%-11 \%$ of total gross primary production (GPP) while burial of C in soils was $\sim 4 \%$ of GPP. Respiration by roots can account for the majority of soil respiration in fringing forests, while microbial processes may account $80 \%$ of respiration in scrub forests. Fertilization of scrub forests with P enhanced GPP but the proportion of C buried declined to $2 \%$ of GPP. Net ecosystem production was $17 \%-27 \%$ of GPP similar to that reported for other mangrove forests. Carbon isotope signatures of adjacent seagrass suggest that dissolved $\mathrm{C}$ from mangroves is exported into the adjacent ecosystems. Our data indicate that $\mathrm{C}$ budgets can vary among mangrove forest types and with nutrient enrichment and that low productivity mangroves provide a disproportionate share of exported C.
\end{abstract}


Keywords: Rhizophora mangle; respiration; fertilization; carbon burial; Belize

\section{Introduction}

Mangrove forests are important sinks of carbon (C) throughout the tropics and subtropics [1-3] due to their high $\mathrm{C}$ burial rates within soils [3-5]. These observations have led to a heightened level of interest in conserving and restoring mangroves for their $C$ values [6,7]. Additionally, mangrove forest primary production is responsible for approximately $10 \%$ of the global export of both particulate and dissolved organic $C$ to the oceans, which supports production in near shore waters [8,9]. However, there are very few detailed $C$ budgets available for mangrove forests $[3,10,11]$. Here, we describe a carbon budget for mangrove forests in Belize. Our aims are to increase knowledge of the global variation in $\mathrm{C}$ budgets of mangroves and the understanding of the factors giving rise to variation in $\mathrm{C}$ stocks, rates of $\mathrm{C}$ burial and the role of mangrove forests in supporting productivity of the coasts on which they occur.

Gross primary productivity (GPP) and the size of the detrital pool in ecosystems are strongly influenced by variation in vegetation structure and rates of turnover [12]. Although little is known of variation in mangrove tree turnover rates [13], mangrove forests vary widely in structure and productivity across large (e.g., latitude [13]) and small spatial scales (e.g., ecotones [14]). Some of the major features of the few existing $\mathrm{C}$ budgets of mangrove forests indicate that despite being rooted in saline soils, they are highly productive forests, with similar productivity to terrestrial forests, and that a large proportion of fixed $\mathrm{C}$ is respired by the canopy $[3,13]$. Carbon burial rates of detritus have been estimated to be approximately $2 \%-4 \%$ of GPP, but this could vary with age of the forest and productivity $[3,11]$. At our study site, C burial is particularly important because of the dependence on the burial of autochthonous organic matter for maintaining the soil elevation relative to sea level $[15,16]$. Finally, approximately $40 \%$ of the fixed $C$ has not yet been accounted for in the existing budgets and is proposed to be exported from the ecosystem [10,13,17], although how the size of the putatively exported fraction varies among different types of mangrove forests is also not known.

Mangrove forests are threatened by agriculture, industry and urbanization [18] which can lead to losses in ecosystem C stocks and alterations to C budgets. Not only are mangrove forests cleared, which results in losses of aboveground and belowground $C[2,19,20]$, but anthropogenic nutrient enrichment alters a range of processes that could affect $C$ budgets [21]. In terrestrial ecosystems, increases in the availability of nutrients have been shown to enhance primary productivity, reduce allocation to roots and increase rates of decomposition of soil organic matter [22,23]. Mangroves also show strong sensitivity to nutrient additions for a range of processes, including above and belowground growth and decomposition [14,24,25]. These studies have demonstrated that scrub mangrove growth can be severely limited by phosphorus (P) availability. However, little is known of how nutrient enrichment influences the efficiency of $\mathrm{C}$ burial within soils through reductions in allocation to roots or enhanced rates of decomposition of soil organic matter.

We used a mass balance approach of $C$ inputs (autotrophic components) and outputs (the fate of autotrophic production) similar to those presented in Alongi [11] to identify the major $\mathrm{C}$ sources and 
sinks of mangrove forests of Twin Cays, Belize. Twin Cays is a small archipelago comprised of 92 ha of mangrove forest that lies within the lagoon of the Meso-American Barrier Reef [26]. In the Caribbean region, mangrove forests often grow on peat soils that overlie limestone [27-29]. Unlike mangrove forests in deltaic systems, where forests often grow on mineral soils, mangrove forest soils in oceanic settings in the Caribbean are often comprised of mangrove roots that have accumulated during the rise in sea level over the Holocene [15]. Accumulation of these peat soils is facilitated by inundation and anoxia which limits decomposition [30]. The mangrove forests of Twin Cays consist of a range of vegetation zones with varying levels of productivity and which are differentially limited by nutrient availability [14]. Tall seaward fringing forests are adjacent to stunted dwarf or scrub forests in the interior of the islands [31]. In addition to stunted trees, microbial mats are well developed in the interior of the islands and have been proposed to be important sites of biogeochemical cycling, including proposed sources of $\mathrm{C}$ and nutrients [32]. Dwarf or scrub trees within the islands interiors show pronounced growth enhancements when fertilized with $\mathrm{P}$, indicating $\mathrm{P}$ limitations to primary productivity in these areas, in contrast to nitrogen limitation to growth observed in the taller seaward fringing forests [14]. Using data from a range of studies, including those focused on long-term fertilization experiments on Twin Cays [24], we assess how forest C budgets vary among different types of mangrove stands and how they are influenced by nutrient enrichment. The intensive research activity at Twin Cays over decades provides an unparalleled, comprehensive insight into elements of the $\mathrm{C}$ budget of these mangrove forests that have rarely been assessed simultaneously in other forests.

\section{Experimental Section}

\subsection{Study Site}

Twin Cays, Belize $\left(16^{\circ} 50^{\prime} \mathrm{N}, 8^{\circ} 06^{\prime} \mathrm{W}\right.$ ) is a small archipelago comprised of 92 ha of mangrove forest that lies within the lagoon of the Meso-American Barrier Reef [26]. The mangroves forests of Twin Cays can be divided into two main vegetation zones: (1) Forests fringing the ocean dominated by Rhizophora mangle, which are approximately 3 to $6 \mathrm{~m}$ tall and occupy approximately 100,000 $\mathrm{m}^{2}$ of the islands; and (2) Dwarf or scrub stands (less than $1.5 \mathrm{~m}$ ) of $R$. mangle and well developed microbial mats that are associated with ponded areas of the interior of islands which cover $\sim 190,000 \mathrm{~m}^{2}$ of the islands area [31,32] (Figure 1). Avicennia germinans and Laguncularia racemosa also occur on the islands in areas of higher elevation, but are excluded from this study because sufficient data are not available to create detailed $\mathrm{C}$ budgets for these vegetation zones. Dwarf or scrub trees within the islands interiors show pronounced growth enhancements when fertilized with P (see insert in Figure 1), indicating $\mathrm{P}$ limitations to primary productivity in these areas, in contrast to nitrogen limitation to growth observed in the taller seaward fringing forests [14].

Data for the construction of $\mathrm{C}$ budgets for Twin Cays, Belize have been acquired over the last 25 years due to the presence of the Smithsonian's field station at nearby Carrie Bow Cay [26] and a range of research initiatives, including the Caribbean Coastal Marine Productivity program (CARICOMP [33]), that have been supported by the Smithsonian Institution and other funding agencies. In order to construct a $\mathrm{C}$ budget for different forest zones (seaward fringing forests and landward scrub forests) and for nutrient enriched (fertilized) and control (non-fertilized) plots, we have 
collated and integrated results from a range of studies that have used a wide array of approaches (Table 1). Much of the data are from long term fertilization experiments that were commenced on Twin Cays in scrub forest in 1988 [34] and extended to cover both fringe and scrub forests in 1995 [14]. Briefly, the fertilization experiments were conducted at three locations in both fringing forests and scrub forests (Figure 1), At each location and in each forest zone nine plots were fertilized with nitrogen $(\mathrm{N}$, applied as urea) and nine fertilized with slow release phosphorus fertilizer $(\mathrm{P})$ with nine remaining as unfertilized controls [14]. In each plot a focal tree was assessed to determine rates of tree growth. As there were no differences among control and $\mathrm{P}$ fertilized trees in the fringing forests for many measured parameters and relatively small differences among $\mathrm{N}$ fertilized and control trees in the fringing forests $[14,15,35]$, and because in the scrub forests there were small differences between $\mathrm{N}$ fertilized and control trees, but very large differences between $\mathrm{P}$ fertilized trees and control trees $[14,15,35,36]$, we chose to focus on contrasts among fringe and scrub forests and within the scrub forest between $\mathrm{P}$ fertilized plots and control plots (Table 1).

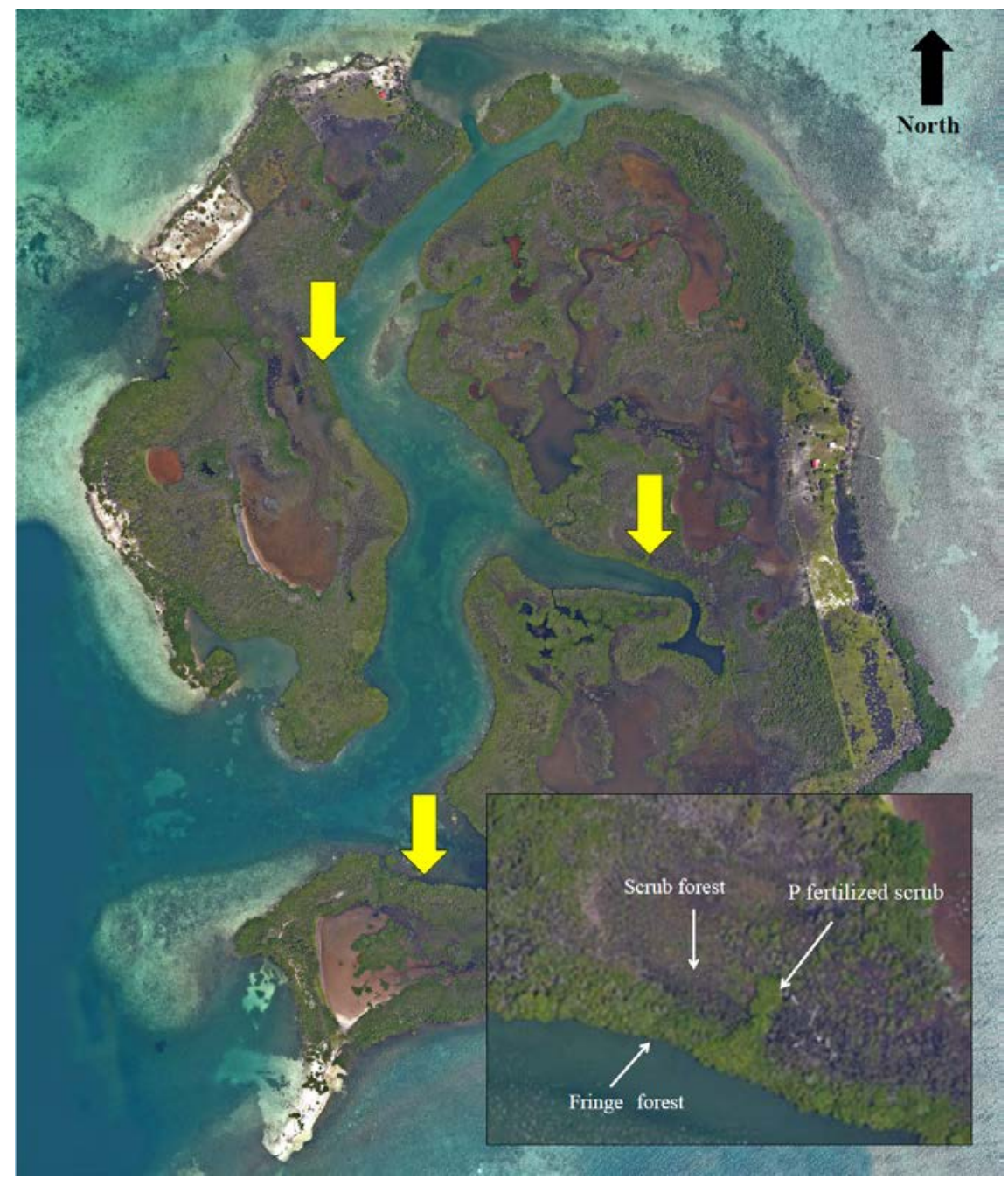

Figure 1. Aerial image of the study site, Twin Cays, Belize in 2006. Study locations are indicated by yellow arrows. The inset provides a detailed view of one of the study locations. Scrub and fringe forests are indicated as well as the phosphorus (P) fertilized scrub trees. 
Table 1. Parameters used in estimating components of the carbon budget of mangrove forests of Twin Cays, Belize. Density of trees is from Koltes et al. [33]; leaf photosynthetic carbon gain is from Lovelock et al. [35] and Cheeseman and Lovelock [36]. Values are means \pm standard errors.

\begin{tabular}{|c|c|c|c|}
\hline \multirow{2}{*}{ Forest Attributes } & \multicolumn{3}{|c|}{ Forest Type } \\
\hline & Fringe & Scrub & P Fertilized Scrub \\
\hline Density of trees No. $\mathrm{m}^{-2}(N=5)$ & $0.51 \pm 0.23$ & $0.23 \pm 0.09$ & $0.23 \pm 0.09$ \\
\hline Tree Height $(N=9)$ & $3.3 \pm 0.2$ & $1.19 \pm 0.10$ & $2.24 \pm 0.22$ \\
\hline $\mathrm{LAI} \mathrm{m}^{2} \cdot \mathrm{m}^{-2}(N=9)$ & $1.82 \pm 0.07$ & $0.39 \pm 0.06$ & $1.70 \pm 0.77$ \\
\hline $\begin{array}{l}\text { Direct measure of canopy leaf area }\left(\mathrm{m}^{2} \cdot \mathrm{m}^{-2}\right) \\
\qquad(N=9)\end{array}$ & $2.62 \pm 0.30$ & $1.17 \pm 0.33$ & $4.61 \pm 0.94$ \\
\hline Surface area stems $\left(\mathrm{m}^{2}\right.$ tree $)$ & $1.3 \pm 0.3$ & $0.06 \pm 0.01$ & $0.46 \pm 0.09$ \\
\hline $\begin{array}{l}\text { Aboveground root length (m length per tree) } \\
\qquad(N=9)\end{array}$ & $62 \pm 20$ & $7.4 \pm 4.0$ & $39 \pm 16$ \\
\hline $\begin{array}{c}\text { Surface area aboveground roots } \\
\left(\mathrm{m}^{2} \text { root area } \mathrm{m}^{-2}\right)\end{array}$ & $5.4 \pm 1.7$ & $0.59 \pm 0.29$ & $2.8 \pm 1.1$ \\
\hline Biomass of macroalgae $\mathrm{g} \cdot \mathrm{m}^{-2}(N=9)$ & $40 \pm 20$ & $8 \pm 8$ & $24 \pm 13$ \\
\hline $\begin{array}{l}\text { Surface area of habitat for macroalgae } \\
\left(\mathrm{m}^{2} \text { root area } \mathrm{m}^{-2}\right)(N=9)\end{array}$ & $0.68 \pm 0.14$ & $0.22 \pm 0.02$ & $0.53 \pm 0.08$ \\
\hline $\begin{array}{l}\text { Leaf photosynthetic carbon gain } \mu \mathrm{mol} \cdot \mathrm{m}^{-2} \cdot \mathrm{s}^{-1} \\
\qquad(N=9)\end{array}$ & $10.3 \pm 0.4$ & $7.4 \pm 0.1$ & $12.1 \pm 0.7$ \\
\hline Leaf respiration $\mu \mathrm{mol} \cdot \mathrm{m}^{-2} \cdot \mathrm{s}^{-1}(N=9)$ & $1.41 \pm 0.06$ & $1.61 \pm 0.04$ & $1.98 \pm 0.12$ \\
\hline
\end{tabular}

P: phosphorus; LAI: leaf area index.

\subsection{Primary Productivity and Respiration of the Canopy, Mats and Macroalgae}

Tree gross primary production (GPP) was estimated by addition of canopy net primary productivity (NPP) to canopy respiration [13]. Leaf area index (LAI) of all forest plots was determined using hemispherical photography analysed with the Hemiview program (Delta T Devices, Cambridge, UK). Canopy NPP was estimated by multiplying the LAI by the mean photosynthetic rate measured in the field (obtained from [35]), which was then scaled up to an annual NPP per plot assuming 10 h per day of photosynthetic activity. Respiration rates of three canopy leaves from each plot were measured at night (in darkness) with the LiCor 6400 standard leaf chamber (Li-Cor, Lincoln, NE, USA). Because LAI incorporates variations in leaf angle (assesses the projected leaf area), and mangroves are known to have steep leaf angles to avoid excess solar radiation and limit water loss $[37,38]$ we also assessed the total leaf area per $\mathrm{m}^{2}$ by harvesting all leaves within a $1 \mathrm{~m}^{2}$ quadrat through the canopy in the fertilization experimental plots (9 per treatment for each forest zone within each of the three study locations). We used this direct measure of leaf area to scale up leaf respiration rates to an annual rate canopy respiration rate by multiplying leaf respiration per leaf area (Table 1 ) by total leaf area per $\mathrm{m}^{2}$ $\times 24 \mathrm{~h} \times 365$ days.

GPP of the microbial mats was obtained from [39,40]. We assumed $100 \%$ cover of the soil surface by these microbial communities [3], but differing productivity over forest zones due to variation in mangrove canopy cover and thus light reaching the benthos [39]. No values of GPP for the mats were available for the $\mathrm{P}$ fertilized trees. We therefore used values for the fringe forest zone anticipating that 
the similar canopy cover (LAI) limited productivity of the mats in the treatment. GPP of the macroalgaal community that is associated with mangrove roots (comprised mainly of Bostrychia tenella, B. montagnei and Catenella repens) was estimated from measures of maximum rates of electron transport from chlorophyll fluorescence using a PAM 2100 (H. Walz, Effeltrich, Germany) and the relationship between carbon gain and electron transport described by Genty et al. [41]. There were no significant differences among photosynthetic rates of the macroalgae over fertilization treatments thus, we used a mean photosynthetic rate of $4.75 \mu \mathrm{mol} \mathrm{C} \mathrm{m}{ }^{-2} \cdot \mathrm{s}^{-1}$ to estimate GPP. Mean

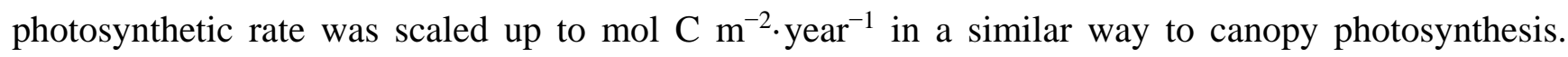
Respiration of algae was measured in air using the Licor 6400 Portable Photosynthesis System (Li-Cor, Lincoln, NE, USA) with the standard leaf chamber in darkness. Values were scaled to GPP on an area basis by multiplication by the area of root macroalgal habitat (aboveground root surface area) measured in $0.25 \mathrm{~m}^{2}$ plots within each experimental plot (Table 1).

\subsection{Other Outputs: Litter Export, Herbivory, Respiration of Woody Tissues and Soils}

Litter fall, litter turnover and forest structure data were obtained for un-manipulated forests from the CARICOMP data sets, which were part of a Caribbean-wide program to assess variation in marine productivity [33]. The CARICOMP procedure includes measurement of all trees within replicate $10 \times 10$ m plots, the deployment of litterfall traps sampled monthly and periodic sampling of leaf litter on the soil surface used to calculate leaf litter turnover. The CARICOMP data set was augmented with another year of data collected on Twin Cays in 2003 using the same procedures Litter fall data was not available from the trees within the fertilization experimental plots and was therefore estimated from leaf initiation rates published in Feller et al. [14]. We assumed a relatively constant number of leaves in the canopy and scaled up to litterfall per $\mathrm{m}^{2}$ area by multiplying leaf production per tree by the density of trees in each vegetation zone. Litterfall estimated in this way was comparable to litterfall measured in the CARICOMP plots. For the $\mathrm{C}$ budget leaf litter was presumed to be exported from the system consistent with the high rates of litter turnover observed at this site [34] and the minor component that leaves contribute to the peat [15]. Losses of leaf material due to herbivory were sourced from Feller and Chamberlain [42].

Wood production was calculated from the mean increment of woody tissues from nine dendrometer bands deployed on stems within the fringing forest for 1 year. We detected no differences among fertilization treatments in wood production in the fringing forest and thus assumed a mean rate of basal area increase of $2.9 \mathrm{~cm}^{2} \cdot$ year $^{-1}$. Tree stems in the fringe had a mean diameter of $11.2 \mathrm{~cm}$. Wood production in the scrub forests was assumed to be low and assigned a zero value. We used a simple approach to convert basal area increment to woody biomass increment of stems by assuming stems are cylindrical with a height of $3 \mathrm{~m}$. To estimate $\mathrm{C}$ accumulation from woody biomass increments we used literature values of wood biomass density for $R$. mangle $\left(0.86 \mathrm{~g} \cdot \mathrm{cm}^{-3}\right)$ and C content of wood (46\% carbon) [43]. Respiration rates of aboveground woody tissues (roots and stems) were calculated from non-destructive measurements of surface area of woody tissues and measurements of respiration from detached tissues harvested from within the experimental plots. Respiration was measured on detached tissues that were approximately 1-2 cm diameter and $7 \mathrm{~cm}$ in length using the $1 \mathrm{~L}$ conifer chamber attached to the LiCor 6400 Portable Photosynthesis System. Respiration was then expressed on a 
surface area basis. Although previous studies in terrestrial trees have indicated that sap wood volume is the most appropriate way to express respiration of woody stems [44] and others have suggested mass is more appropriate [45], we used surface area as a proxy for the amount of respiring tissues (cambium) rather than volume or mass because a study of whole tree respiration in mangroves from Japan indicated that while respiration was explained adequately by mass in rapidly growing trees, surface area may be a better predictor in slower growing trees. That is, respiration is better explained by mass to the exponent $2 / 3$ or $3 / 4$ rather than $1[46,47]$. Respiration of woody tissues was scaled to a rate $\mathrm{m}^{-2}$. year $^{-1}$ by multiplication by the surface area of aboveground roots and stems. Total surface area of woody tissues per tree was estimated by field measurements of tree architecture. Diameter, length of branches, and number of branches arising from each branch was recorded for representative stems and aboveground roots at each branching order on each of the focal trees within the fertilization experiments. The number of main stems (trunks) was assessed then for each branching order it was assumed, based on our observations, that only one branch (of possible three) continued to support the next branching order. To obtain the total area of stem surface area per tree the area of stem from all stems arising from the main stems were multiplied by the number of main stems. To estimate root surface area we followed a similar process assessing the number of main roots arising from the base of the stem and then assessing the diameter and length of all branching orders for the focal trees within the fertilization experiments.

Soil respiration was measured when soils were exposed in air using the LiCor 6400 with soil flux chamber attached. The chamber was placed at the sediment surface, penetrating only $5 \mathrm{~mm}$ of the sediment, to avoid severing surface roots $[48,49]$. The production of fine and coarse roots was obtained from McKee [50] who measured root production using in-growth bags within the fertilization experimental plots. Carbon burial within soils was calculated from mean increases in soil surface elevation over time, which was measured over the peat depth of 9-12 m (depth to the benchmark) [15] multiplied by the mean $\mathrm{C}$ density of soils obtained from [50]. Carbon density in this study was assessed from small cores (5 cm in diameter and $20 \mathrm{~cm}$ depth) from each plot which were dried and finely ground before analysis using an elemental analyser (EA 1110, CE Instruments, Milan, Italy) [50]. Root respiration from each plot was measured on detached fine roots in moist air using a custom built root respiration chamber attached to the LiCor 6400 Portable Photosynthesis System [51].

\subsection{Data Analysis}

Statistical tests were not appropriate for the descriptive $\mathrm{C}$ budgets presented as values were collated over a many different studies using a range of different approaches that did not always adhere to a similar experimental design. Regression analysis was used to assess the relationship between GPP and C burial in soils. 


\section{Results and Discussion}

\subsection{Gross Primary Productivity}

Gross primary production was higher in fringing forests than scrub forests and higher still in the P fertilized scrub forests (Table 2). A larger portion of GPP was attributed to the microbial mat production in the scrub $(\sim 27 \%)$ compared to the fringing forest $(\sim 2.5 \%)$ and the $\mathrm{P}$ fertilized trees ( 2\%). The contribution to GPP of the epiphytic macroalgal community that adheres to the roots (i.e., Bostrychia and Catenella) was low in the interior scrub forest and highest in the seaward fringing forest where tidal inundation is frequent. The mean biomass of these communities was $8 \pm 8 \mathrm{~g} \cdot \mathrm{m}^{-2}$ (mean $\pm \mathrm{SE}$ ) for the scrub forests and $40 \pm 20 \mathrm{~g} \cdot \mathrm{m}^{-2}$ in the fringing forest (Table 1). The macroalgal community contributes $3.7 \%$ of total community GPP in P fertilized scrub, $5.6 \%$ in the scrub and $8.9 \%$ in the fringing forest.

Table 2. Summary carbon budget (mol $\mathrm{C} \mathrm{m}^{-2} \cdot \mathrm{year}^{-1}$ ) of fringing and scrub

Rhizophora mangle forests and phosphorus fertilized scrub forests for Twin Cays, Belize.

\begin{tabular}{cccc}
\hline Budget Components & \multicolumn{3}{c}{ Forest Type } \\
\cline { 2 - 4 } & Fringe & Scrub & Fertilized P Scrub \\
\hline INPUTS & 378.0 & 89.0 & 555.0 \\
Mangrove trees & 38.0 & 7.5 & 22.0 \\
Epiphytic algal community & 11.0 & 36.5 & 11.0 \\
Microbial mat & $\mathbf{4 2 7 . 0}$ & $\mathbf{1 3 3 . 0}$ & $\mathbf{5 8 8 . 0}$ \\
TOTAL INPUTS & & & \\
OUTPUTS & 132.0 & 51.0 & 286.0 \\
Canopy respiration & 47.0 & 8.6 & 81.5 \\
Soil respiration & 108.0 & 29.0 & 168.0 \\
Aboveground root respiration & 18.6 & 3.2 & 36.5 \\
Stem respiration & 8.2 & 1.6 & 4.8 \\
Algal respiration & 11.6 & 0.1 & 15.0 \\
Wood production & 1.2 & 0.4 & 1.6 \\
Herbivory & 17.6 & 2.8 & 12.9 \\
Burial in soil & 13.1 & 0.8 & 13.1 \\
Export (litter) & 357.3 & $\mathbf{9 7 . 5}$ & $\mathbf{6 1 9 . 4}$ \\
TOTAL OUTPUTS & $69.6(16.3)$ & $35.5(26.7)$ & $-31.4(-5.3 \%)$ \\
\% C of GPP buried & 4.1 & 2.1 & 2.2 \\
Net Ecosystem Production (NEP) (\% GPP) & 1.19 & 1.36 & 0.95 \\
\hline Production:Respiration ratio (P:R) & & &
\end{tabular}

Within the same island, different habitats (seaward fringing forests and scrub or dwarf habitats) can have vastly different levels of productivity and have differences in the sources and fates of fixed C. The mangrove canopy is responsible for most GPP, but soil surface microbial communities accounted for $27 \%$ of GPP in the scrub compared to $2.5 \%$ in the fringing forest. These values are consistent with the limited development of the canopy in scrub forests, which at this site is due to $\mathrm{P}$ limitations to tree growth $[14,34,52]$. 


\subsection{Autotrophic Respiration}

There were differences between aboveground root tissue and aboveground stem tissues in respiration rates (Table 1). We used a respiration rate of $3.3 \mu \mathrm{mol} \mathrm{CO} 2 \mathrm{~m}^{-2} \cdot \mathrm{s}^{-1}$ for aboveground roots and $1.27 \mu \mathrm{mol} \mathrm{m} \mathrm{m}^{-2} \cdot \mathrm{s}^{-1}$ for woody stem tissues in order to scale-up aboveground woody tissue respiration to the whole tree and stand level. Respiration of aboveground components (leaves, stems, aboveground roots) accounted for a large proportion of GPP in seaward fringing forests (68\%), scrub forests (94\%) and P fertilized scrub (88\%). These values reflect the large aboveground root biomass that occurs in these forests (Table 1). We estimated $7.1 \pm 3.9 \mathrm{~m}$ of aboveground root length per tree in scrub trees ( $0.6 \mathrm{~m}^{2}$ surface area), $61 \pm 20 \mathrm{~m}$ (5.4 $\mathrm{m}^{2}$ surface area) in seaward fringing trees and $39 \pm 16 \mathrm{~m}$ (2.8 $\mathrm{m}^{2}$ surface area) for $\mathrm{P}$ fertilized scrub trees.

Our $\mathrm{C}$ budget indicates, similar to other forests that respiration of the biomass accounts for the largest fraction of GPP [13]. We found that aboveground roots and stems are a significant respiratory sink with values similar to canopy respiration in the fringing forest, and values proportionally lower in the scrub and P fertilized scrub. Rhizophora mangle under flooded (and nutrient limited) conditions produces a large biomass of aboveground roots [53]. This component of mangrove tree metabolism has rarely been explicitly included in $\mathrm{C}$ budgets but could be a large factor in some forests, particularly where primary production is low but aboveground root biomass is high [54].

The magnitude of our estimate of respiration of woody tissues could be overestimated because: (1) Aboveground roots and twigs of mangroves are photosynthetically active [55,56], which at high levels of solar radiation (as occurs in the scrub forest) may reclaim respired $\mathrm{CO}_{2}$. Measurements in other mangrove species indicate the epidermis of roots and twigs remove $90 \%$ of incident photosynthetic radiation [57], thus, over estimation of respiration from woody tissues would most likely occur in the scrub habitats where woody tissues are exposed to high levels of solar radiation compared to fringing habitats where aboveground roots are shaded by the canopy; (2) Rates of respiration measured in detached tissues may be higher than that for intact trees. Rates of stem respiration measured in pine species [41] were lower than the values we observed. Ryan et al. [43] observed values of $0.2-0.6 \mu \mathrm{mol} \mathrm{CO}_{2} \mathrm{~m}^{-2} \cdot \mathrm{s}^{-1}$ while our aboveground tissues had mean values of $1.44 \mu \mathrm{mol} \mathrm{CO} \mathrm{Cm}^{-2} \cdot \mathrm{s}^{-1}$ and aboveground roots even higher at $3.8 \mu \mathrm{mol} \mathrm{CO} \mathrm{Cm}^{-2} \cdot \mathrm{s}^{-1}$. In contrast, fine root respiration rates of $R$. mangle were lower than most other species [50]. But, high levels of aerenchyma tissues that occur in aboveground roots of mangroves may impose a high metabolic cost as well as high respiration rates in aboveground roots and stems [58]. Given the sensitivity of respiration to temperature and rising levels of atmospheric $\mathrm{CO}_{2}$ [59], further work is required to fully understand this component of mangrove forest $\mathrm{C}$ budgets. Over-estimation of the respiration of woody tissue would increase the unaccounted for fraction of $\mathrm{C}$ in the budget (the net ecosystem production, NEP), potentially leading to an underestimation of $C$ available for export (described below).

Other output components of the $\mathrm{C}$ budget are comparatively small and within the range observed in other studies. Litter production was similar to that predicted by the relationship between precipitation and export of litter [60]. Wood production was also similar to that measured in other low productivity mangrove forests [61], accounting for 3\% of GPP in fringing forest and P fertilized scrub but lower $(<1 \%)$ in the scrub forests. Losses to canopy herbivory are $<1 \%$ of GPP. Wood feeding insects contribute to woody tissue turnover [62] and may therefore contribute to the wood production term 
in the budget (7\% of fringing forest GPP) and to $\mathrm{C}$ burial due to incorporation of dead wood into the soil profile $[49,63]$.

\subsection{Soil Respiration}

Soil respiration accounted for 11\% in fringing forests, $6.5 \%$ in fringing forests and $14 \%$ of GPP in $\mathrm{P}$ fertilized scrub forests (Table 2). Using values of root respiration and annual root production rates from [15], we estimated the proportion of soil respiration that may be due to root metabolism (Table 3). Approximately $100 \%$ of soil respiration could be due to root respiration in the seaward fringing forest and $\mathrm{P}$ fertilized scrub forests, while only $20 \%$ of soil respiration can be accounted for by root respiration in the scrub habitat, the balance (80\%) is then attributed to respiration of the microbial community.

Table 3. Rates of soil respiration in mol $\mathrm{C} \mathrm{m}^{-2} \cdot \mathrm{year}^{-1}$ from mangrove forests of Twin Cays, Belize and estimates of the components of soil respiration due to root respiration and respiration of the microbial community.

\begin{tabular}{cccc}
\hline \multirow{2}{*}{ Budget Components } & \multicolumn{3}{c}{ Forest Type } \\
\cline { 2 - 4 } & Fringe & Scrub & P fertilized Scrub \\
\hline Soil Respiration & 61.2 & 34.7 & 92.7 \\
\hline $\begin{array}{c}\text { Root respiration } \\
\text { (stock } \times \text { respiration rate) }\end{array}$ & 64.2 & 6.9 & 102.4 \\
\hline $\begin{array}{c}\text { Microbial respiration (by difference) } \\
\text { (\% of soil respiration) }\end{array}$ & $-3.0(-5 \%)$ & $27.8(80 \%)$ & $-9.7(-10 \%)$ \\
\hline
\end{tabular}

That respiration of roots could completely account for soil respiration in both the seaward fringing forests and P fertilized scrub forest suggests low activity of the heterotrophic microbial community, consistent with high level of accumulation of organic matter in mangrove ecosystems [1-5]. Our estimates of the amount of live roots are probably underestimated because under control conditions (not fertilized) root mortality was not observed during the experiments of McKee et al. [15]. In Florida, fine to small roots had longevities of 1.7 to 4.4 years [64], indicating that the abundance of live roots may be much larger than annual production and thus root respiration could be $\sim 2$ to 4 times higher than our conservatively estimated value. Studies in terrestrial forests have also found that root respiration can be a major component of soil respiration [65]. However, respiration of the microbial community contributed $80 \%$ of the $\mathrm{CO}_{2}$ flux in the scrub habitats. The $\mathrm{C}$ sources and nutrients supporting microbial respiration in the scrub forests are derived from litter and the microbial mats $[37,38]$ but may also be from the mangrove peat. High rates of $\mathrm{CO}_{2}$ emissions were observed following clearing of mangroves at Twin Cays [18] suggesting that the peat may be decomposed under some conditions [66] and also that living tree roots may suppress decomposition of soil organic matter [67]. Although anoxia due to tidal flooding contributes to slow rates of decomposition of soil C in mangroves, other factors, potentially associated with productivity of trees, e.g., competition for limiting P, may also play important roles in suppressing microbial metabolism and thus decomposition of soil organic matter [67]. 


\subsection{Carbon Burial}

Carbon burial in soils, calculated from annual rates of soil surface accretion and $\mathrm{C}$ density of soils was higher in the seaward fringing forests $\left(17.6 \mathrm{~mol} \mathrm{C} \mathrm{m}^{-2} \cdot \mathrm{year}^{-1}\right)$ than in the scrub forests (2.8 $\mathrm{mol} \mathrm{C} \mathrm{m}^{-2} \cdot \mathrm{year}^{-1}$ ) and the P fertilized scrub (12.9 mol C m$\left.{ }^{-2} \cdot \mathrm{year}^{-1}\right)$. These were $4.1 \%$ of GPP in the seaward fringe and $2.1 \%$ of GPP in both scrub and P fertilized scrub (Table 2).

Carbon burial in soils in the fringing forest and $\mathrm{P}$ fertilized scrub trees were similar to the global mean of $10.8 \mathrm{~mol} \mathrm{C} \mathrm{m}^{-2} \cdot$ year $^{-1}$ [4]. Extrapolation of these rates using the area of habitat on Twin Cays indicates that the $R$. mangle dominated fringe and scrub forests sequesters $\sim 27.5 \mathrm{Mg} \mathrm{C}_{\text {year }}{ }^{-1}$ (or about $100 \mathrm{Mg} \mathrm{CO} 2$ equivalents per year) which is $\sim 0.02 \%$ of the total $\mathrm{CO}_{2}$ emissions of Belize in 2008 (116 Gg of C [68]). Using areas of scrub and tall/fringing mangrove habitat for the whole country of Belize [69] suggests that nation-wide $\mathrm{C}$ burial by these mangrove habitats is $61,600 \mathrm{Mg} \mathrm{C} \mathrm{year}{ }^{-1}$, which is $\sim 50 \%$ Belize's nation-wide reported $\mathrm{CO}_{2}$ emissions. The sheer magnitude of the $\mathrm{C}$ burial by mangrove habitats in Belize warrants their conservation and restoration where they have been lost.

By combining our values of $C$ burial with those in the literature [11] and unpublished values, we found that $\mathrm{C}$ burial tends to increase with increasing productivity of the forests (Figure 2). Moreover, fringing forests in Mexico (similar to Belize) were observed to have higher stocks of soil $\mathrm{C}$ in fringe (987 Mg C ha ${ }^{-1}$ ) compared to scrub (381 $\mathrm{Mg} \mathrm{C} \mathrm{ha}^{-1}$ ) [28]. These findings indicate that soil C stocks accumulated over time may be a function of stable, long term patterns in environmental conditions and productivity over mangrove landscapes in this region.

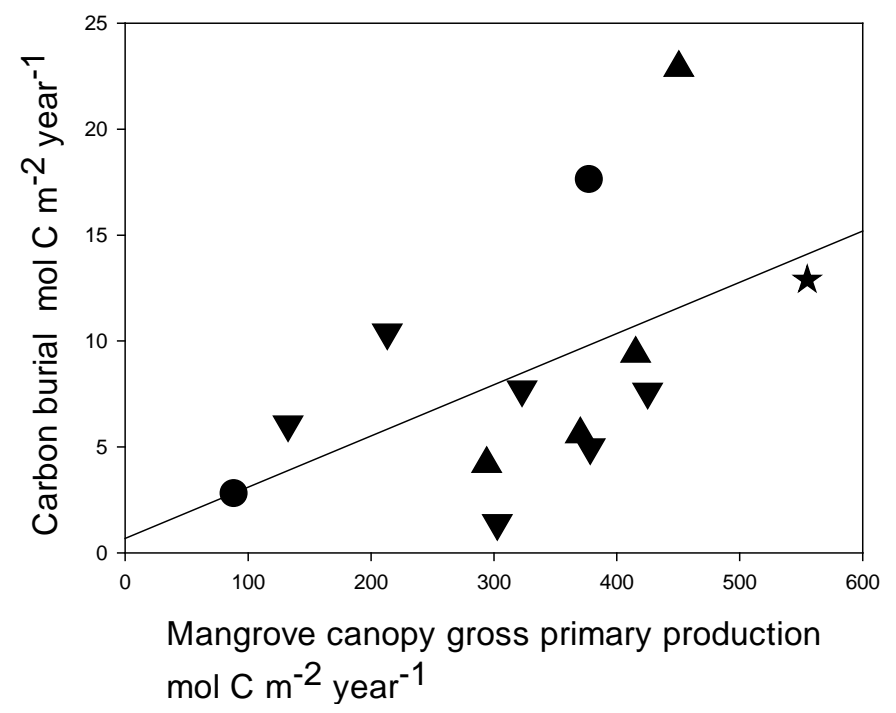

Figure 2. Variation in carbon burial with gross productivity of mangrove canopies. Data is from Alongi [11] (upward triangles), Lovelock et al. [70,71] Moreton Bay, downward triangles) and this study (scrub and fringe forests are circles, $\mathrm{P}$ fertilized scrub a star). The form of the curve is $y=0.682 \times 0.0242 x, R^{2}=0.27$.

The proportion of GPP that was buried in the fringing forests (4.1\%) was higher than that of the scrub forest (2.1\%), suggesting more favorable conditions for $\mathrm{C}$ burial in fringing forests. However, given the flooded nature of the scrub soils and the low redox potential in these areas [52], we expected the scrub forests to have higher proportional $\mathrm{C}$ burial as anoxia reduces decomposition rates of organic 
matter. Instead, the higher productivity fringing forest had higher proportional rates of $\mathrm{C}$ burial. Alongi [66] has suggested that some, as yet unidentified aspects of productive mangrove forests, may decrease decomposition of organic matter and increase $\mathrm{C}$ burial.

Fertilization with $\mathrm{P}$, despite higher productivity of trees, resulted in a smaller proportional burial of carbon (2\%) compared to the fringing forest (4\%). This observation is consistent with lower proportional allocation of GPP to roots in fertilized plants that has been observed in other "wild" plants [22]. However, the ratio of root production to GPP is 4\% in scrub forest and $6 \%$ in both fringing forests and $\mathrm{P}$ fertilized scrub trees. Therefore, rather than differences in proportional allocation to roots, alternative hypotheses to explain differences in proportional $\mathrm{C}$ burial between forests zones and with fertilization include: (1) Differences in rates of decomposition may be responsible for the reduced proportional C burial in P fertilized plants compared to fringing forests; or (2) Differences in root structure may contribute to reduced proportional C burial in $\mathrm{P}$ fertilized trees. Using a standardized test comparing the tensile strength of buried cotton strips, decomposition was found to be enhanced in $\mathrm{P}$ fertilized plots compared to control sites [14], supporting the hypothesis that rates of decomposition increases with $\mathrm{P}$ fertilization. Phosphorus (and iron) limitation of the microbial community has been suggested previously in other mangrove forests [72]. The addition of excess $\mathrm{P}$ may lead to increased decomposition of soil $\mathrm{C}$ and thereby reduce rates of $\mathrm{C}$ burial. Variation in root structure in mangroves has not been described over nutrient gradients and thus remains to be assessed as a factor influencing $\mathrm{C}$ burial in mangroves.

\subsection{Variation in Net Ecosystem Production}

In the seaward fringing forest, $16 \%$ of GPP and $27 \%$ of scrub forests GPP could not be accounted for and thus is assumed to be NEP in the mass balance budget (Table 2). This contrasted with the P fertilized scrub forest where the budget was balanced within 5\% (inputs of fixed $\mathrm{C}$ was totally accounted for in the outputs measured or estimated). Correspondingly, production to respiration (P:R) ratios in the seaward fringing forest were 1.2, 1.4 and 0.95 for the fringing, scrub and $\mathrm{P}$ fertilized scrub, respectively.

The presence of well-developed surface microbial mats is an important feature of mangrove habitats contributing both to GPP [38,39] and to reducing diffusion of respired $\mathrm{CO}_{2}$ across the soil surface thereby leading to under estimations of soil respiration $[47,48,68]$. Experiments where surface films were removed (scraped off) indicated that soil respiration increased by approximately $60 \%$ compared to when the surface was intact $[47,68,73]$. Possibly as a consequence of this reduced rate of diffusion, very high concentrations of dissolved inorganic $\mathrm{C}$ and low $\mathrm{pH}$ (6.5) are observed in the soil porewater (16 mmol in scrub forests compared to $1.5 \mathrm{mmol}$ in the fringe soils [32,38]). These high levels of dissolved inorganic carbon (DIC) could be due to root respiration as well as decomposition of microbial (and algal) detritus and also decomposition of soil organic matter derived from mangrove tissues (Table 1). Bouillon et al. [74] estimated that porewater contributed a large component (18\%-87\%) of creek water. The interior ponds at Twin Cays are known to drain through creeks [75]. Photographic evidence indicates drainage of dissolved coloured organic material from the mangrove islands via creeks and subterranean channels [76]. Additionally, the $\mathrm{C}$ isotopic signature $\left(\delta^{13} \mathrm{C}\right)$ of seagrass on the edges of the mangrove islands is 7 per mil less $(-14)$ compared to seagrass associated 
with the nearby coral reef [77]. The low value $\left(\delta^{13} \mathrm{C}\right.$ of -14$)$ indicates that seagrass on the edge of the mangrove are using an additional DIC source that is more negative than that in the seawater and may be mangrove in origin [78]. Mangroves have a $\delta^{13} \mathrm{C}$ of approximately -26 to -29 , while algae and cyanobacteria are substantially higher [79]. Thus, mangrove root respiration or decomposition of mangrove derived soil organic matter is likely to contribute to DIC exported from the scrub forests and interior ponds.

Despite the potential errors using mass balance approaches (because of errors in large fluxes e.g., GPP and respiration [11]), our estimates of NEP were similar to that observed in other mangrove forest C budgets $[3,10,11,13]$. NEP is proposed to be exported from the ecosystem as DIC rather than dissolved organic carbon (DOC), which is known to be low [59]. Measurements of NEP of mangroves in Florida using eddy-covariance techniques gave a value of $97.5 \mathrm{~mol} \mathrm{~m}^{-2}$.year ${ }^{-1}$ of which they estimate $25 \%-70 \%$ of NEP is likely to be exported [80]. This is similar in magnitude to our estimates of NEP for fringing mangroves in our study $\left(70 \mathrm{~mol} \mathrm{C} \mathrm{m}^{-2} \cdot\right.$ year $\left.^{-1}\right)$ but higher than that measured for scrub mangroves (35 mol C m${ }^{-2}$ year ${ }^{-1}$ ). Our values of NEP for Twin Cays are slightly lower than values reported for Australian and Asian mangrove forests which range from 101-178 mol C me. year $^{-1}$ [11,16] and globally, $118 \mathrm{~mol} \mathrm{C} \mathrm{m}^{-2} \cdot$ year $^{-1}$ [10]. Maher et al. [81] bserved that DIC export from mangroves in subterranean groundwater flow was driven by tidal pumping. Despite the very low tidal range at Twin Cays $(<50 \mathrm{~cm})$, photographic evidence and observed $\delta^{13} \mathrm{C}$ of adjacent seagrass suggest that export of DIC from porewater is a plausible fate for the unaccounted for carbon at Twin Cays. Given the area of fringing forests is $\sim 100,000 \mathrm{~m}^{2}$ ha and scrub forest and interior ponds comprise $\sim 190,000 \mathrm{~m}^{2}$ of the island vegetation [31], and if we assume $100 \%$ of NEP is exported, annual rates of DIC export from forests at Twin Cays could be $835 \mathrm{Gg} \cdot$ year $^{-1}$ for fringing habitats and $809 \mathrm{Gg} \cdot$ year $^{-1}$ for scrub forests, indicating that despite lower productivity, scrub forests may be an important source of exported C. Export of DIC may have influence on other habitats within the lagoon including the lagoon microbial community, seagrass beds, sponges and coral reefs.

\section{Conclusions}

There are few detailed $\mathrm{C}$ budgets for mangrove forests and the impact of nutrient enrichment, which is a serious threat in the coastal zone, has not yet been explicitly considered. From our $\mathrm{C}$ budget for Twin Cays, we contribute to the overall understanding of mangrove $\mathrm{C}$ cycling by finding that microbial mats can provide a significant proportion of GPP in scrub habitats, respiration of aboveground roots and stems may be a significant source of respired C, and that the processes contributing to soil respiration differ across habitats, with the microbial community making a greater contribution in the scrub forests than in more productive fringing forests. Additionally, we found that C burial is a small proportion of GPP (2\%-4\%) which is correlated with GPP of forests, and which may, with more data collected over time, lead to development of predictive relationships between GPP and rates of soil $\mathrm{C}$ burial in mangrove ecosystems. But the proportion of GPP that is buried in soils decreased with fertilization, in this case with $\mathrm{P}$, suggesting that the efficiency of $\mathrm{C}$ burial to soils in these habitats may have declined where nutrient enrichment of the coastal zone has occurred. The impacts of nutrient enrichment may therefore include reduced soil surface elevation gains, which may increase vulnerability of mangrove ecosystems to sea level rise. Finally, we find NEP is $16 \%-27 \%$ of 
GPP, similar to that observed in other mangrove C budgets. Scrub forests may contribute a high proportion of NEP because of enhanced decomposition of organic matter compared to fringing forests. There is isotopic evidence to suggest NEP is exported to the adjacent waters around the islands where it may contribute to productivity of adjacent ecosystems.

\section{Acknowledgments}

We thank Anne Chamberlain, Rainer Feller, the participants of the Mangrove Biocomplexity project and the staff of the Carrie Bow Cay Research Station and Pelican Beach Resort. This research was funded by the National Science Foundation (DEB-9981535) and the Smithsonian Institution's Marine Science Network. We thank the Australian Research Council (awards DP0774491, DP0986179, DP1096749 and FS100100024) and the Marine and Coastal Carbon Biogeochemistry Cluster for their support.

\section{Author Contributions}

All authors contributed data. C.E.L. wrote the manuscript while L.T.S., L.J.D. and I.C.F. edited the manuscript.

\section{Conflicts of Interest}

The authors declare no conflict of interest.

\section{References and Notes}

1. Chmura, G.L.; Anisfeld, S.C.; Cahoon, D.R.; Lynch, J.C. Global carbon sequestration in tidal, saline wetland soils. Glob. Biogeochem. Cycles 2003, 17, 1111, doi:10.1029/2002GB001917.

2. Donato, D.C.; Kauffman, J.B.; Murdiyarso, D.; Kurnianto, S.; Stidham, M.; Kanninen, M. Mangroves among the most carbon-rich forests in the tropics. Nat. Geosci. 2011, 4, 293-297.

3. Alongi, D.M. Carbon cycling and storage in mangrove forests. Annu. Rev. Mar. Sci. 2014, 6, 195-219.

4. Duarte, C.M.; Middelburg, J.J.; Caraco, N. Major role of marine vegetation on the oceanic carbon cycle. Biogeosciences 2005, 2, 1-8.

5. Mcleod, E.; Chmura, G.L.; Bouillon, S.; Salm, R.; Bjork, M.; Duarte, C.M.; Lovelock, C.E.; Schlesinger, W.H.; Silliman, B. A Blueprint for Blue Carbon: Towards an improved understanding of the role of vegetated coastal habitats in sequestering $\mathrm{CO}_{2}$. Front. Ecol. Environ. 2011, 9, 552-560.

6. Pendleton, L.; Donato, D.C.; Murray, B.C.; Crooks, S.; Jenkins, W.A.; Sifleet, S.; Craft, C.; Fourqurean, J.W.; Kauffman, J.B.; Marba, N.; et al. Estimating global "Blue Carbon” emissions from conversion and degradation of vegetated coastal ecosystems. PLoS ONE 2012, 7, e43542.

7. Siikamäki, J.; Sanchirico, J.N.; Jardine, S.L. Global economic potential for reducing carbon dioxide emissions from mangrove loss. Proc. Natl. Acad. Sci. USA 2012, 109, 14369-14374.

8. Jennerjahn, T.C.; Ittekkot, V. Relevance of mangroves for the production and deposition of organic matter along tropical continental margins. Naturwissenschaften 2002, 89, 23-30. 
9. Dittmar, T.; Hertkorn, N.; Kattner, G.; Lara, R.J. Mangroves, a major source of dissolved organic carbon to the oceans. Glob. Biogeochem. Cycles 2006, 20, doi:10.1029/2005GB002570.

10. Bouillon, S.; Borges, A.V.; Castaneda-Moya, E.; Diele, K.; Dittmar, T.; Duke, N.C.; Kristensen, E.; Lee, S.Y.; Marchand, C.; Middelburg, J.J.; et al. Mangrove production and carbon sinks: A revision of global budget estimates. Glob. Biogeochem. Cycles 2008, 22, doi:10.1029/2007GB003052.

11. Alongi, D.M. Carbon sequestration in mangrove forests. Carbon Manag. 2012, 3, 313-322.

12. Cebrian, J.; Duarte, C.M. Plant growth-rate dependence of detrital carbon storage in ecosystems. Science 1995, 5217, 1606-1608.

13. Alongi, D.M. Energetics of Mangrove Ecosystems; Springer Science \& Business Media: New York, NY, USA, 2009.

14. Feller, I.C.; McKee, K.L.; Whigham, D.F.; O’Neill, J.P. Nitrogen vs. phosphorus limitation across and ecotonal gradient in a mangrove forest. Biogeochemistry 2003, 62,145-175.

15. McKee, K.L.; Cahoon, D.R.; Feller, I.C. Caribbean mangroves adjust to rising sea level through biotic controls on change in soil elevation. Glob. Ecol. Biogeogr. 2007, 16, 545-556.

16. Wooller, M.J.; Behling, H.; Smallwood, B.J.; Fogel, M. Mangrove ecosystem dynamics and elemental cycling at Twin Cays, Belize, during the Holocene. J. Quat. Sci. 2004, 19, 703-711.

17. Maher, D.T.; Eyre, B.D. Carbon budgets for three autotrophic Australian estuaries: Implications for global estimates of the coastal air-water $\mathrm{CO}_{2}$ flux. Glob. Biogeochem. Cycles 2012, 26, doi:10.1029/2011GB004075.

18. Alongi, D.M. Mangrove forests: Resilience, protection from tsunamis, and responses to global climate change. Estuar. Coast. Shelf Sci. 2002, 76, 1-13.

19. Lovelock, C.E.; Ruess, R.W.; Feller, I.C. $\mathrm{CO}_{2}$ efflux from cleared mangrove peat. PLoS ONE 2011, 6, e21279.

20. Kauffman, J.B.; Heider, C.; Norfolk, J.; Payton, F. Carbon stocks of intact mangroves and carbon emissions arising from their conversion in the Dominican Republic. Ecol. Appl. 2014, 24, 518-527.

21. Reef, R.; Feller, I.C; Lovelock, C.E. Nutrition of mangroves. Tree Physiol. 2010, 30, 1148-1160.

22. Chapin, F.S. Mineral nutrition of wild plants. Annu. Rev. Ecol. Syst. 1980, 11, 233-260.

23. Tilman, D. Secondary succession and the pattern of plant dominance along experimental nitrogen gradients. Ecol. Monogr. 1987, 57, 189-214.

24. Feller, I.C.; Lovelock, C.E.; Piou, C. Growth and nutrient conservation in Rhizophora mangle in response to fertilization along latitudinal and tidal gradients. Smithson. Contrib. Mar. Sci. 2009, 38, 345-358.

25. Feller, I.C.; Lovelock, C.E.; Berger, U.; McKee, K.L.; Joye, S.B.; Ball, M.C. The biocomplexity of mangrove ecosystems. Annu. Rev. Mar. Sci. 2010, 2, 395-416.

26. Ruetzler, K.; Feller, I.C. Caribbean mangrove swamps. Sci. Am. 1996, 274, 94-99.

27. Macintyre, I.G.; Littler, M.M.; Littler, D.S. Holocene history of Tobacco Range, Belize, Central America. Atoll Res. Bull. 1995, 43, 1-18.

28. Woodroffe, C.D. Mangrove vegetation of Tobacco Range and nearby mangrove ranges, central Belize barrier reef. Atoll Res. Bull. 2005, 427, 1-35. 
29. Adame, M.F.; Kauffman, J.B.; Medina, I.; Gamboa, J.N.; Torres, O.; Caamal, J.P.; Reza, M.; Herrera-Silveira, J.A. Carbon stocks of tropical coastal wetlands within the karstic landscape of the Mexican Caribbean. PLoS ONE 2013, 8, e56569.

30. Middleton, B.A.; McKee, K.L. Degradation of mangrove tissues and implications for peat formation in Belizean island forests. J. Ecol. 2001, 89, 818-828.

31. Rodriguez, W.; Feller, I.C. Mangrove landscape characterization and change in Twin Cays, Belize using aerial photography and IKONOS satellite data. Atoll Res. Bull. 2004, 513, 1-24.

32. Lee, R.Y.; Joye, S.B. Patterns and controls on nitrogen fixation and denitrification in intertidal soils of a tropical oceanic mangrove island. Mar. Ecol. Prog. Ser. 2006, 307, 127-41.

33. Koltes, K.; Tschirky, J.; Feller, I.C. Carrie Bow Cay, Belize. In Caribbean Coastal Marine Productivity (CARICOMP): Caribbean Coral Reef, Seagrass and Mangrove Sites Characteristics; Coastal Region and Small Island Papers 3; Kjerfve, B., Ed.; UNESCO: Paris, France, 1998; pp. 79-94.

34. Feller, I.C. Effects of nutrient enrichment on growth and herbivory of dwarf red mangrove Rhizophora mangle. Ecol. Monogr. 1995, 65, 477-505.

35. Lovelock, C.E.; Ball, M.C.; Choat, B.; Engelbrecht, B.M.J.; Holbrook, N.M.; Feller, I.C. Linking physiological processes with mangrove forest structure: Phosphorus deficiency limits canopy development; hydraulic conductivity and photosynthetic carbon gain in dwarf Rhizophora mangle. Plant Cell Environ. 2006, 29, 793-802.

36. Cheeseman, J.C.; Lovelock, C.E. Photosynthetic characteristics of dwarf and fringe Rhizophora mangle in a Belizean mangrove. Plant Cell Environ. 2004, 27, 768-780.

37. Ball, M.C.; Cowan, I.R.; Farquhar, G.D. Maintenance of leaf temperature and the optimisation of carbon gain in relation to water loss in a tropical mangrove forest. Aust. J. Plant Physiol. 1988, 15, 263-267.

38. Lovelock, C.E.; Clough, B.F. Influence of solar radiation and leaf angle on leaf xanthophyll concentrations in mangroves. Oecologia 1992, 91, 518-525.

39. Lee, R.Y.; Porubsky, W.P.; Feller, I.C.; McKee K.L.; Joye, S.B. Porewater biogeochemistry and soil metabolism in dwarf red mangrove habitats (Twin Cays; Belize). Biogeochemistry 2008, 87, 181-198.

40. Joye, S.B.; Lee, R.Y. Benthic microbial mats: Important sources of fixed nitrogen and carbon to the Twin Cays, Belize ecosystem. Atoll Res. Bull. 2004, 528, 1-24.

41. Genty, B.; Briantas, J.-M.; Baker, N.R. The relationship between quantum yield of photosynthetic electron transport and quenching of chlorophyll fluorescence. Biochim. Biophys. Acta 1989, 990, 87-92.

42. Feller, I.C.; Chamberlain, A.H. Herbivore responses to nutrient enrichment and landscape heterogeneity in a mangrove ecosystem. Oecologia 2007, 153, 607-616.

43. Kauffman, J.B.; Heider, C.; Cole, T.; Dwire, K.A.; Donato, D.C. Ecosystem carbon pools of Micronesian mangrove forests: Implications of land use and climate change. Wetlands 2011, 31, 343-352.

44. Ryan, M.G.; Gower, S.T.; Hubbard, R.M.; Waring, R.H.; Gholz, H.L.; Cropper Jr, W.P.; Running, S.W. Woody tissue maintenance respiration of four conifers in contrasting climates. Oecologia 1995, 101, 133-140. 
45. Reich, P.B.; Tjoelker, M.G.; Machado, J.L.; Oleksyn, J. Universal scaling of respiratory metabolism, size and nitrogen in plants. Nature 2006, 439, 457-461.

46. Hoque, A.T.M.R.; Sharma, S.; Suwa, R.; Hagihara, A. Seasonal variation in the size-dependent respiration of mangroves Kandelia obovata. Mar. Ecol. Prog. Ser. 2010, 404, 31-37.

47. Mori, S.; Yamaji, K.; Ishida, A.; Prokushkinc, S.G.; Masyaginac, O.V.; Hagiharad, A.; Hoqued A.T.M.R.; Suwad, R.; Osawae, A.; Nishizono, T. et al. Mixed-power scaling of whole-plant respiration from seedlings to giant trees. Proc. Natl. Acad. Sci. 2010, 107, 1447-1451.

48. Lovelock, C.E. Soil respiration in tropical and subtropical mangrove forests. Ecosystems 2008, 11, 342-354.

49. Lovelock, C.E.; Feller, I.C.; Reef, R.; Ruess, R.W. Variable effects of nutrient enrichment on soil respiration in mangrove forests. Plant Soil 2015, 379, 135-148.

50. McKee, K.L. Biophysical controls on accretion and elevation change in Caribbean mangrove ecosystems. Estuar. Coast. Shelf Sci. 2011, 91, 475-483.

51. Lovelock, C.E.; Ruess, R.W.; Feller, I.C. Root respiration in Rhizophora mangle over variation in forest stature and nutrient availability. Tree Physiol. 2006, 26, 1601-1606.

52. McKee, K.L.; Feller, I.C.; Popp, M.; Wanek, W. Mangrove isotopic fractionation $\left(\delta^{15} \mathrm{~N}\right.$ and $\left.\delta^{13} \mathrm{C}\right)$ across a nitrogen versus phosphorus limitation gradient. Ecology 2002, 83, 1065-75.

53. Ellison, A.M.; Farnsworth, E.J. Spatial and temporal variability in growth of Rhizophora mangle saplings on coral cays: Links with variation in insolation, herbivory, and local sedimentation rate. J. Ecol. 1996, 84, 717-731.

54. Lugo, A.E. Old-growth mangrove forests in the United States. Conserv. Biol. 1997, 11, 11-20.

55. Kitaya, Y.; Yabuki, K.; Kiyota, M.; Tani, A.; Hirano, T.; Aiga, I. Gas exchange and oxygen concentration in pneumatophores and prop roots of four mangrove species. Tree Struct. Funct. 2002, 16, 155-158.

56. Schmitz, N.; Egerton, J.J.G.; Lovelock, C.E.; Ball, M.C. Light-dependent maintenance of hydraulic function in mangrove branches: Do xylary chloroplasts play a role in embolism repair? New Phytol. 2012, 195, 40-46.

57. Material not intended for publication: C.E. Lovelock (The University of Queensland, St Lucia, QLD). Transmittance of light through epidermal tissues of aboveground roots of Rhizophora sp., 2013.

58. Drew, M.C.; Saglio, P.H.; Pradet, A. Larger adenylate energy charge and ATP/ADP ratios in aerenchymatous roots of Zea mays in anaerobic media as a consequence of improved internal oxygen transport. Planta 1985, 165, 51-58.

59. King, J.S.; Hanson, P.J.; Bernhardt, E.; DeAngelis, P.; Norby, R.J.; Pregitzer, K.S. A multiyear synthesis of soil respiration responses to elevated atmospheric $\mathrm{CO}_{2}$ from four forest FACE experiments. Glob. Chang. Biol. 2004, 10, 1027-1042.

60. Adame, M.F.; Lovelock, C.E. Carbon and nutrient exchange of mangrove forests with the coastal ocean. Hydrobiologia 2011, 663, 23-50.

61. Day, J.W.; Coronado-Molina, C.; Vera-Herrera, F.R.; Twilley, R.; Rivera-Monroy, V.H.; Alvarez-Guillen, H.; Day, R.; Conner, W. A 7 year record of above-ground net primary production in a southeastern Mexican mangrove forest. Aquat. Bot. 1996, 55, 39-60. 
62. Feller, I.C. The role of herbivory by wood-boring insects in mangrove ecosystems in Belize. Oikos 2002, 97, 167-76.

63. Krauss, K.W.; McKee, K.L.; Lovelock, C.E.; Cahoon, D.R.; Saintilan, N.; Reef, R.; Chen, L. How mangrove forests adjust to rising sea level. New Phytol. 2014, 202, 19-34.

64. Castaneda-Moya, E.; Twilley, R.R.; Rivera-Monroy, V.H.; Marx, B.D.; Coronado-Molina, C.; Ewe, S.M. Patterns of root dynamics in mangrove forests along environmental gradients in the Florida Coastal Everglades, USA. Ecosystems 2011, 14, 1178-1195.

65. Hogberg, P.; Nordgren, A.; Buchmann, N.; Taylor, A.F.; Ekblad, A.; Högberg, M.N.; Nyberg, G.; Ottosson-Löfvenius, M.; Read, D.J. Large-scale forest girdling shows that current photosynthesis drives soil respiration. Nature 2001, 411, 789-90.

66. Keuskamp, J.A.; Schmitt, H.; Laanbroek, H.J.; Verhoeven, J.T.; Hefting, M.M. Nutrient amendment does not increase mineralisation of sequestered carbon during incubation of a nitrogen limited mangrove soil. Soil Biol. Biochem. 2013, 57, 822-829.

67. Alongi, D.M.; de Carvalho, N.A.; Amaral, A.L. Uncoupled surface and below-ground soil respiration in mangroves: implications for estimates of dissolved inorganic carbon export. Biogeochemistry 2012, 109, 151-162.

68. Anon. Carbon Dioxide Information and Analysis Center. Available online: http://cdiac.ornl.gov/ trends/emis/blz.html (accessed on 1 September 2015).

69. Murray, M.R.; Zismana, S.A.; Furleya, P.A.; Munro, D.M.; Gibson, J.; Ratter, J.; Bridgewater, S.; Minty, C.D.; Place, C.J. The mangroves of Belize Part 1. Distribution, composition and classification. For. Ecol. Manag. 2003, 174, 265-279.

70. Material not intended for publication: C.E. Lovelock (The University of Queensland, St Lucia, QLD). Estimates of Gross Primary Production for mangrove forests in Moreton Bay, derived from assessment of LAI and photosynthetic rates of leaves; and estimates of carbon burial derived from assessment of soil accretion and soil carbon density, 2013.

71. Lovelock, C.E.; Adame, M.F.; Bennion, V.; Hayes, M.; O’Mara, J.; Reef, R.; Santini, N. Contemporary rates of carbon sequestration through vertical accretion of sediments in mangrove forests and saltmarshes of South East Queensland, Australia. Estuar. Coasts, 2013, doi:10.1007/s12237-013-9702-4.

72. Alongi, D.M. Dissolved iron supply limits early growth of estuarine mangroves. Ecology 2011, 91, 3229-3241.

73. Leopold, A.; Marchand, C.; Debordeb, J.; Chaduteau, C.; Allenbach, M. Influence of mangrove zonation on $\mathrm{CO}_{2}$ fluxes at the sediment-air interface (New Caledonia). Geoderma 2012, 202-203, $62-70$.

74. Bouillon, S.; Middleburg, J.J.; Dehairs, F.; Borges, A.V.; Abril, G.; Flindt, M.R.; Ulomi, S.; Kristensen, E. Importance of intertidal sediment processes and porewater exchange on the water column biogeochemistry in a pristine mangrove creek (Ras Dege, Tanzania). Biogeosciences 2007, 4, 311-322.

75. Urish, D.W.; Wright, R.M.; Feller, I.C.; Rodriguez, W. Dynamic hydrology of a mangrove island: Twin Cays, Belize. Smithson. Contrib. Mar. Sci. 2009, 38, 473-490.

76. Feller, I.C. (Smithsonian Environmental Research Center, Edgewater, MD, USA). Aerial photographs from light aircraft. 2011. 
77. Feller, I.C.; Baker, R. (Smithsonian Environmental Research Center, Edgewater, MD, USA). Stable isotope composition of seagrass at Twin Cays, 2013.

78. Lin, G.; Banks, T.; Sternberg, L.S.L.O. Variation in $\delta^{13} \mathrm{C}$ values for the seagrass Thalassia testudinum and its relations to mangrove carbon. Aquat. Bot. 1991, 40, 333-341.

79. Raven, J.A.; Johnston, A.M.; Kübler, J.E.; Korb, R.; McInroy, S.G.; Handley, L.L.; Scrimgeour, C.M.; Walker, D.I.; Beardall, J.; Vanderklift, M.; et al. Mechanistic interpretation of carbon isotope discrimination by marine macroalgae and seagrasses. Funct. Plant Biol. 2002, 29, 355-378.

80. Barr, J.G.; Engel, V.; Fuentes, J.D.; Zieman, J.C.; O’Halloran, T.L.; Smith, T.J.; Anderson, G.H. Controls on mangrove forest-atmosphere carbon dioxide exchanges in western Everglades National Park. J. Geophys. Res. 2010, 115, doi:10.1029/2009JG001186.

81. Maher, D.T.; Santos, I.R.; Golsby-Smith, J.; Gleeson, J.; Eyre, B.D. Groundwater-derived dissolved inorganic and organic carbon exports from a mangrove tidal creek: The missing mangrove carbon sink? Limnol. Oceanogr. 2013, 58, 475-488.

(C) 2015 by the authors; licensee MDPI, Basel, Switzerland. This article is an open access article distributed under the terms and conditions of the Creative Commons Attribution license (http://creativecommons.org/licenses/by/4.0/). 